\title{
PENGEMBANGAN MEDIA PEMBELAJARAN BERBASIS PAPAN PERMAINAN "JUMANJI PHYSICS" PADA POKOK BAHASAN MOMENTUM IMPULS UNTUK MENINGKATKAN HASIL BELAJAR PESERTA DIDIK KELAS X SMA 17AGUSTUS1945 SURABAYA
}

\author{
Agung Prasetyo ${ }^{\text {a) }}$, Anthony Wijaya ${ }^{\text {b) }}$ \\ Program Studi Pendidikan Fisika, Universitas Katolik Widya Mandala Surabaya, Surabaya, Indonesia \\ Email: a)prasetyoagung2509@gmail.com, b) anthony@ukwms.ac.id
}

\begin{abstract}
Abstrak
Pengembangan media pembelajaran berbasis papan permainan "Jumanji Physics" pada pokok bahasan momentum impuls untuk meningkatkan hasil belajar peserta didik merupakan penelitian yang bertujuan untuk mengetahui kualitas media pembelajaran berbasis papan permainan yang dikembangkan. Model penelitian yang digunakan adalah Research and Development (R\&D) dengan model pengembangan ADDIE yang terdiri dari lima tahap Analysis, Design, Develop, Implement, dan Evaluation. Media pembelajaran yang dikembangkan beriskan materi momentum impuls. Pada tahap analisis kebutuhan peserta didik, $88,89 \%$ peserta didik menyatakan membutuhkan media pembelajaran berbasis papan permainan untuk lebih membantu memahami materi fisika. Subyek penelitian adalah siswa kelas $\mathrm{X}$ SMA 17 Agustus 1945 Surabaya berjumlah 90 orang. Media ini dilengkapi dengan perangkat pembelajaran meliputi RPP dikategorikan sangat valid dan RE dikategorikan valid oleh ahli. Media pembelajaran yang dikembangkan dikategorikan sangat valid oleh ahli. Rata - rata penilaian peer review dalam uji terbatas mengkategorikan media ini sangat baik. Hasil belajar siswa dinilai berdasarkan hasil pre-test dan post-test, dihasilkan nilai N-Gain sebesar 0,65 dan berada dalam kategori sedang. Keterlaksanaan RPP dikategorikan sangat baik. Berdasarkan angket respon peserta didik memberikan respon positif dengan kategori baik.
\end{abstract}

Kata-kata kunci: Jumanji Physics, media pembelajaran berbasis permainan, impuls momentum

\begin{abstract}
Board game-based learning media development of "Jumanji Physics" to improve student's learning results on momentum impuls is a research that aims to determine the quality of the board game-based learning media developed. The research model used is Research and Development (R\&D) with the ADDIE development model which consists of five stages of Analysis, Design, Develop, Implement, and Evaluation. Learning media that are developed contain material momentum impulses During the students' needs analysis, $88.89 \%$ of students stated that they needed media based on game learning to better understand physics concepts. The subjects of the study were 90 students of class X 17 Agustus 1945 Senior High School Surabaya. This media is equipped with learning devices including RPP categorized as very valid and RE is categorized as valid by experts. The learning media developed are
\end{abstract}


categorized as very valid by experts. The average assessment of peer review in a limited test categorizes this media very well. Student learning results are assessed based on the results of the pre-test and posttest, resulting in the N-Gain value of 0.65 and in the medium category. The implementation of lesson plans is categorized very well. Based on the response questionnaire, students gave positive responses in good categories.

Keywords: Jumanji Physics, board game-based learning media, momentum impulse

\section{PENDAHULUAN}

Manusia yang berpendidikan akan selalu berkembang ke arah yang lebih baik dalam kehidupannya. Di setiap zaman pasti akan mengalami perubahan-perubahan yang mengarah pada kemajuan pendidikan yang lebih baik. Maka dari itu diperlukan adanya berbagai inovasi untuk kemajuan kualitas pendidikan yang tidak hanya menekankan pada teori tapi juga yang bersifat praktis.

Keberhasilan pembelajaran ditandai dengan perolehan pengetahuan keterampilan, dan sikap positif pada diri individu, sesuai dengan tujuan yang diharapkan. Keberhasilan belajar ini sangat dipengaruhi oleh banyak faktor, dan salah satunya adalah penggunaan media pembelajaran yang berfungsi sebagai perantara, wadah, atau penyambung pesan-pesan pembelajaran. Media berfungsi mengarahkan peserta didik untuk memperoleh berbagai pengalaman belajar. Pengalaman belajar tergantung pada interaksi peserta didik dengan media [1].

Penggunaan media pengajaran sangat penting bagi proses belajar dan mengajar. Dikatakan demikian karena media pembelajaran sangat membantu pendidik atau pengajar dalam memberikan pengajaran secara maksimal, efektif, serta efisien. Namun tidak semua media pembelajaran sesuai atau cocok untuk diterapkan pada semua kondisi dan materi yang akan diberikan. Oleh karena itu, pemilihan media yang tepat untuk mata pelajaran tertentu menjadi hal yang penting untuk diperhatikan. Jika media yang digunakan kurang tepat sehingga menyebabkan siswa menjadi bosan dalam belajar maka media tersebut dikatakan gagal dan tidak bermanfaat bagi peserta didik. Maka dari itu pemilihan media haruslah yang bersifat menyenangkan supaya siswa tertarik untuk belajar. Hal ini dilakukan demi memenuhi kebutuhan dan tercapainya tujuan pembelajaran.

Berdasarkan uraian diatas peneliti membuat pengembangan media pembelajaran berupa papan permainan "Jumanji Physics". Media ini memiliki beberapa keunggulan dibandingkan media pembelajaran yang lain, yaitu (1)permainan adalah sesuatu yang menyenangkan untuk dilakukan, sesuatu yang menghibur, (2)permainan memungkinkan adanya partisipasi aktif dari siswa untuk belajar, (3)permainan dapat memberikan umpan balik langsung, (4)permainan memungkinkan penerapan konsep-konsep ataupun peran-peran ke dalam penyelesaian suatu masalah, (5)permainan bersifat luwes, (6)permainan dapat dengan mudah dibuat dan diperbanyak [2]. Oleh karena itu penulis melakukan penelitian yang berjudul "Pengembangan Media Pembelajaran Berbasis Papan Permainan Jumanji Physics pada Pokok Bahasan Momentum Impuls untuk Meningkatkan Hasil Belajar Peserta Didik Kelas X SMA 17 Agustus 1945 Surabaya"

\section{METODOLOGI}

Metode yang digunakan dalam penelitian ini adalah metode penelitian pengembangan (Research Development Method) dan menggunakan model ADDIE (Analysis-Design-Develop-ImplementEvaluate) [4]. Pada penelitian ini lebih ditekankan dalam pembuatan sesuatu, menguji di lapangan, merevisinya sehingga mendapatkan hasil yang baik. 


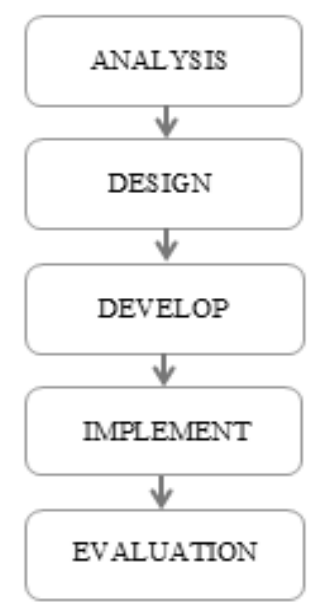

GAMBAR 1. Bagan Model Pengembangan ADDIE.

1. Tahap Analysis, peneliti melakukan analisis kebutuhan peserta didik dalam pembelajaran khususnya mengenai urgensi kebutuhan media pembelajaran. Melalui tahap ini dianalisis mengenai kebutuhan media dalam pembelajaran Fisika yang di ukur melalui angket kebutuhan peserta didik

2. Tahap Design, peneliti merumuskan design atau perancangan media pembelajaran berbasis papan permainan dari hasil analisis kebutuhan yang telah didapatkan pada tahap analysis untuk dapat melengkapi media pembelajaran yang akan dikembangkan. Selanjutnya peneliti merancang tampilan dan isi dari media pembelajaran berbasis papan permainan dengan materi momentum impuls.

3. Tahap Develop (pengembangan) merupakan tahapan dimana peneliti akan merealisasikan hasil dari tahap design. Produk yang dihasilkan pada penelitian ini adalah media pembelajaran yang berupa 1 set media pembelajaran berbasis papan permainan "Jumanji Physics" untuk materi momentum impuls. Kemudian dalam tahap ini peneliti harus melewati suatu proses yang dinamakan validasi produk. Validasi produk digunakan untuk mengetahui kelayakan dari media pembelajaran yang telah dibuat. Validasi produk akan dilakukan oleh ahli media dan ahli materi fisika. Kelayakan media dapat dilihat dari kesesuaian produk dengan tujuan yang ingin dicapai peneliti. Masukan-masukan dari validator akan digunakan untuk memperbaiki media pembelajaran sebelum uji lapangan dilakukan.

4. Tahap Implement, peneliti mengimplementasikan hasil produk berupa media pembelajaran berbasis papan permainan "Jumanji Physics" untuk materi momentum impuls di SMA 17 Agustus 1945 Surabaya kelas X-MIPA 1, X-MIPA 2 dan X-MIPA 3. Sebelum melakukan uji lapangan peneliti melakukan uji terbatas pada mahasiswa Fisika Universitas Katolik Widya Mandala Surabaya. Masukan-masukan dari uji terbatas akan digunakan untuk memperbaiki media pembelajaran untuk dapat digunakan uji lapangan di SMA 17 Agustus 1945 Surabaya.

5. Tahap Evaluation, peniliti melakukan analisa data dari hasil implementasi di tempat pengujian. Secara umum, proses evaluasi ini diperlukan untuk mengetahui pengaruh produk pengembangan berupa media pembelajaran berbasis papan permainan berbasis papan permainan "Jumanji Physics" terhadap hasil belajar peserta didik. Tahap evaluasi juga terjadi pada setiap tahapan model pengembangan ADDIE untuk kebutuhan revisi dengan sebutan evaluasi formatif [5]

Lembar Validasi Media Pembelajaran meliputi kriteria yang akan di nilai oleh validator yaitu, tampilan media, isi materi, dan bahasa yang digunakan. Peneliti membuat lembar validasi dengan menggunakan penilaian dengan skala 1-5. Kemudian peneliti mengolah hasil tiap aspek, selanjutnya dari hasil rata-rata tersebut akan dikonversi menjadi data kualitatif sesuai dengan TABEL 1. 
TABEL 1. Kategori Penilaian Skala Lima

\begin{tabular}{|c|c|}
\hline Interval Skor & Kategori \\
\hline$\overline{\boldsymbol{x}}>\overline{\boldsymbol{x}_{i}}+1,8 \mathrm{Sb}_{\mathrm{i}}$ & Sangat Baik \\
\hline$\overline{\boldsymbol{x}_{z}}+0,6 \mathrm{Sb}_{\mathrm{i}}<\overline{\boldsymbol{x}} \leq \overline{\boldsymbol{x}_{\imath}}+1,8 \mathrm{Sb}_{\mathrm{i}}$ & Baik \\
\hline$\overline{\boldsymbol{x}_{\boldsymbol{v}}}-0,6 \mathrm{Sb}_{\mathrm{i}}<\overline{\boldsymbol{x}} \leq \overline{\boldsymbol{x}_{\boldsymbol{v}}}+0,6 \mathrm{Sb}_{\mathrm{i}}$ & Cukup \\
\hline$\overline{\boldsymbol{x}_{\boldsymbol{\imath}}}-1,8 \mathrm{Sb}_{\mathrm{i}}<\overline{\boldsymbol{x}} \leq \overline{\boldsymbol{x}_{\boldsymbol{t}}}-0,6 \mathrm{Sb}_{\mathrm{i}}$ & Kurang \\
\hline$\overline{\boldsymbol{x}} \leq \overline{\boldsymbol{x}_{\boldsymbol{t}}}-1,8 \mathrm{Sb}_{\mathrm{i}}$ & Sangat Kurang \\
\hline
\end{tabular}

Keterangan:

$\bar{x} \quad=$ Skor aktual

$\bar{x}_{a} \quad=$ Rata-rata skor ideal $=1 / 2($ skor maksimum ideal + skor minimum ideal $)$

$\mathrm{Sb}_{\mathrm{i}} \quad=$ Simpangan baku ideal $=1 / 6$ (skor maksimum ideal - skor minimum ideal)

Peneliti melakukan uji lapangan kepada subyek sasaran penelitian yakni pada peserta didik kelas X MIPA-1, X-MIPA 2 dan X-MIPA 3 SMA 17 Agustus 1945 Surabaya dengan menggunakan rancangan uji lapangan yang diterapkan adalah One Group Pre-test Post-test Design. Pre-test diujikan pada peserta didik sebelum mendapatkan materi serta media pembelajaran yang akan diberikan. Kegiatan tersebut bertujuan untuk mengetahui kemamapuan peserta didik akan materi momentum, impuls dan tumbukan. Sehingga pre-test menghasilkan nilai awal peserta didik sebelum menerima materi yang akan di berikan.

Post-test diujikan pada peserta didik sesudah mendapatkan materi dan media pembelajaran. Kegiatan tersebut bertujuan untuk mengetahui hasil belajar peserta didik setelah mendapatkan materi yang didukung oleh media pembelajaran. Selanjutnya dari hasil pre-test dan post-test dianalisa untuk mendapatkan Normalize Gain Score [3]. Selanjutnya ditinjau sesuai dengan kategori pada TABEL 2.

$$
N-\text { Gain }=\frac{S_{\text {post }}-S_{\text {pre }}}{S_{\max }-S_{\text {pre }}}
$$

Keterangan:

$S_{\text {post }}=$ nilai post-test tiap peserta didik

$S_{\text {pre }} \quad=$ nilai pre-test tiap peserta didik

$S_{\max }=$ nilai maksimal

TABEL 2. Kategori Penilaian Skala Lima

\begin{tabular}{cc}
\hline Interval $N$-gain & Kategori \\
\hline $0,70<N$-Gain & Tinggi \\
\hline $0,30 \leq N$-Gain $\leq 0,70$ & Sedang \\
\hline$N$-Gain $<0,30$ & Rendah \\
\hline
\end{tabular}

Angket respon peserta didik, lembar respon peserta didik diisi oleh peserta didik yang bertujuan untuk mengetahui apakah media pembelajaran yang dibuat oleh peneliti dapat di terima dengan baik oleh peserta didik, selanjutnya lembar angket akan diberikan kepada peserta didik setelah melakukan kegiatan post-test. Dengan angket tersebut peneliti dapat membuat skala penilaian 1 sampai dengan 4, selanjutnya peneliti menganalisis dengan menggunakan TABEL 1 .

\section{HASIL DAN PEMBAHASAN}

Hasil penelitian ini merupakan produk media pembelajaran yang dinilai oleh ahli mencakup: Validasi perangkat pembelajaran seperti RPP (Rencana Pelaksanaan Pembelajaran) dan Rencanan Evaluasi (RE) serta Validasi Media Pembelajaran.

Media pembelajaran ini dibuat dengan tujuan untuk meningkatkan hasil belajar peserta didik, oleh karena itu media pembelajaran yang dibuat berisikan materi momentum impuls. Berikut adalah bagian dari media pembelajaran: 


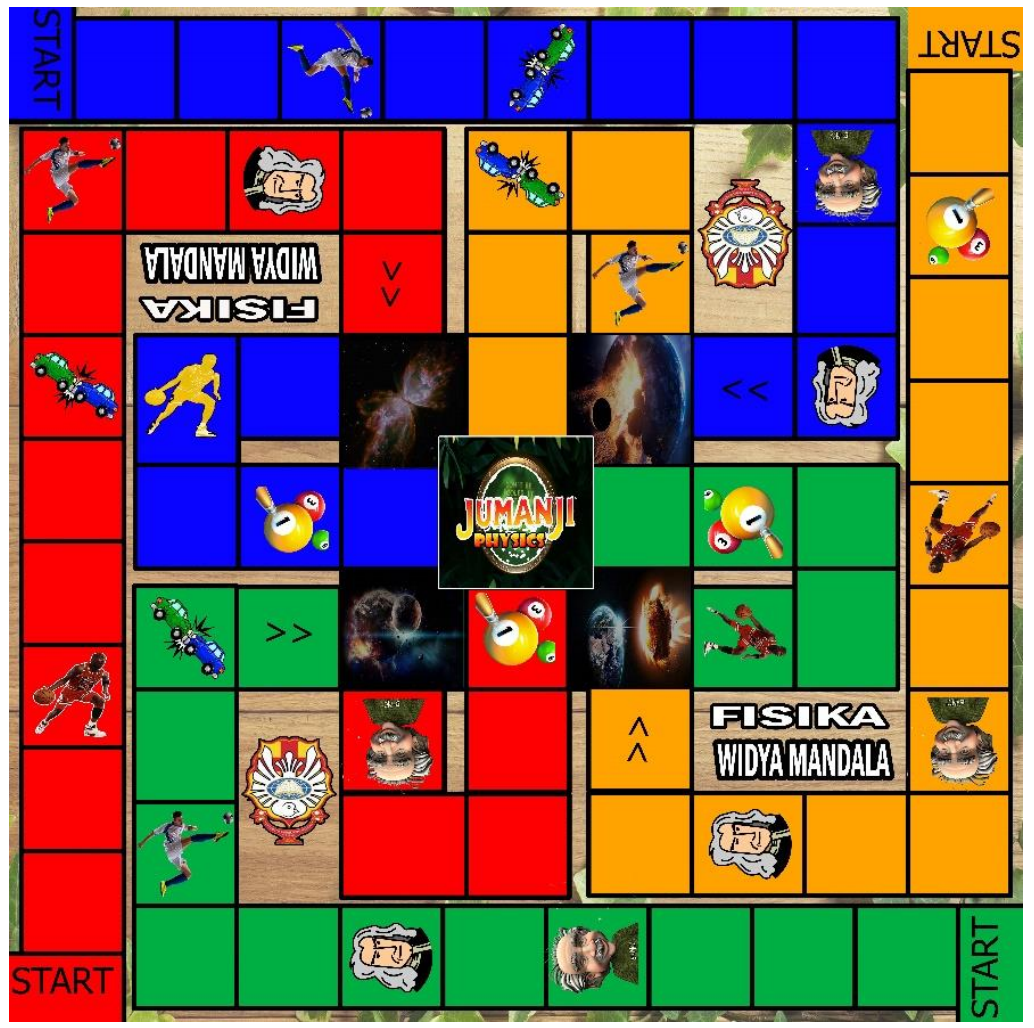

(a)
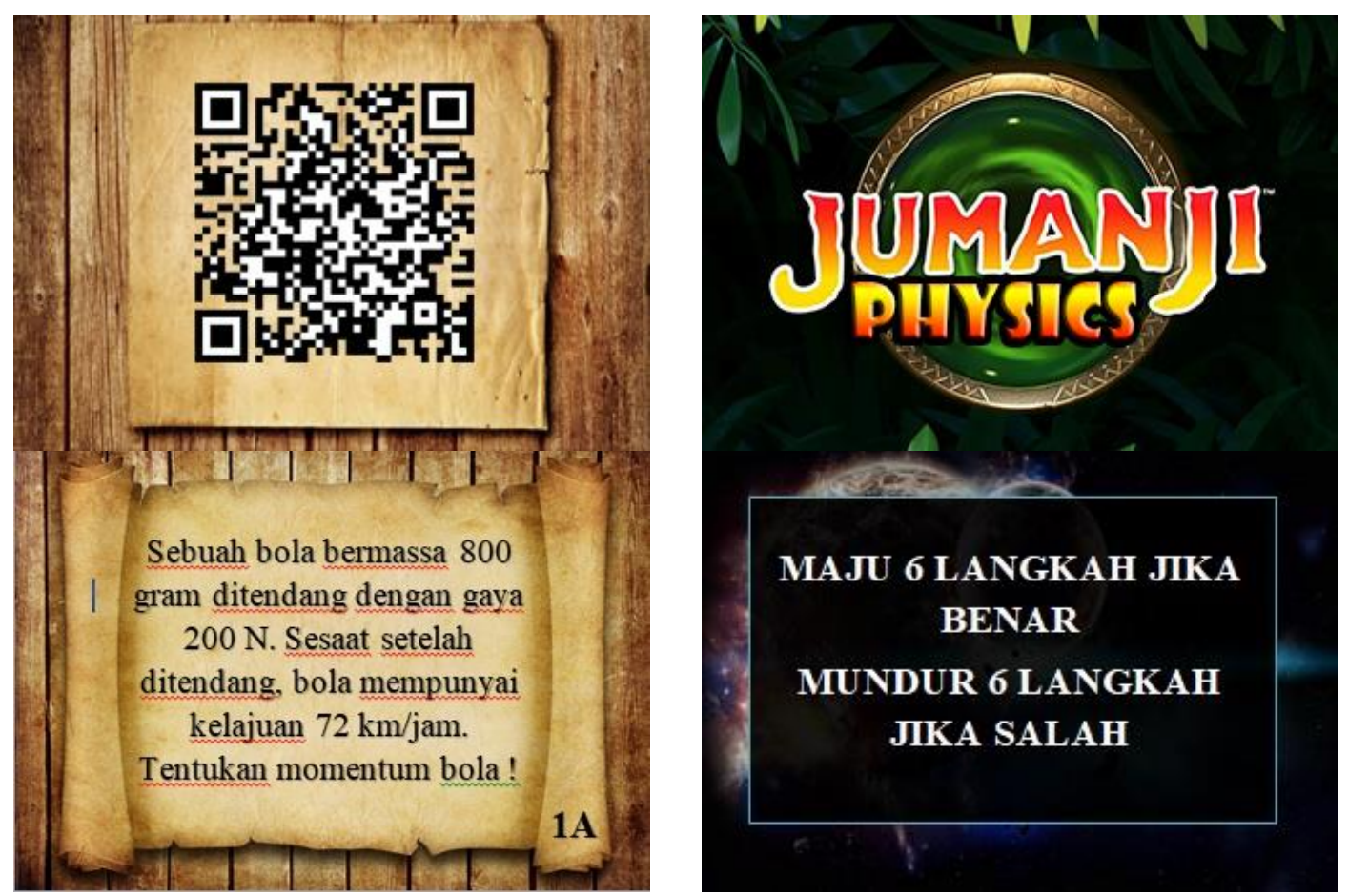

GAMBAR 2. (a) Desain Papan Permainan Jumanji Physics (b) Desain Kartu Soal tampak depan (c) Desain Kartu Soal tampak belakang (d) Desain Kartu Soal setelah di scan (e) Desain Kartu "Beta" 


\section{Analisis Tahap Pengembangan}

Melaui tahap Develop (Pengembangan) media pembelajaran berbasis papan permainan Jumanji Physics yang telah dikonsultasikan dengan dosen pembimbing skripsi. Media pembelajaran ini juga telah melalui komparasi dengan pembelajaran dengan media berbasis game yang telah diimplementasikan [6]. Media pembelajaran yang telah divalidasi oleh validator ahli dengan indikator yang telah disesuaikan dengan pengembangan media pembelajaran sejenis terkait media, media pembelajaran, pembelajaran berbasis game, dan joyful [7-10]. Hasil dapat dilihat pada rata-rata nilai seperti pada TABEL 3. Sedangkan untuk hasil dari penilaian media pembelajaran oleh peer reviewer dapat dilihat pada TABEL 4.

TABEL 3. Rata-Rata Skor Validasi Media oleh Ahli

\begin{tabular}{lll}
\hline Aspek & Nilai Rata-Rata & Kategori \\
\hline Isi Media & 4.14 & Baik \\
\hline Materi & 4.57 & Sangat Baik \\
\hline Rata-Rata & $\mathbf{4 . 3 6}$ & Sangat Baik \\
\hline
\end{tabular}

TABEL 4. Rata-Rata Skor Penilaian Media oleh Peer Reviewer

\begin{tabular}{lll}
\hline Aspek & Nilai Rata-Rata & Kategori \\
\hline Tampilan & 3.63 & Sangat Baik \\
\hline Materi & 3.59 & Sangat Baik \\
\hline Keterlaksanaan & 3.48 & Sangat Baik \\
\hline Rata-Rata & $\mathbf{3 . 5 7}$ & Sangat Baik \\
\hline
\end{tabular}

Dari hasil penilaian media pembelajaran oleh validator ahli mendapatkan rata-rata nilai sebesar 4,36 dengan kategori sangat baik. Sedangkan hasil penilaian oleh peer reviewer mendapatkan rata-rata nilai 3,57, dengan kategori sangat baik. Adapun saran-saran yang diberikan oleh validator ahli dan peer reviewer yang relevan digunakan untuk memperbaiki media pembelajaran yang dibuat oleh peneliti sebelum diuji cobakan pada skala yang lebih besar di kelas.

Uji lapangan dilakukan di SMA 17 Agustus 1945 Surabaya kelas X-MIPA 1, X-MIPA 2 dan XMIPA 3 dengan jumlah 90 peserta didik. Metode yang digunakan oleh peneliti adalah one group pre-test post test. Untuk mengetahui kemampuan siswa diawal, peneliti melakukan pre-test dengan jumlah soal yang diberikan kepada peserta didik ada 7 butir soal, waktu yang diberikan pada saat mengerjakan adalah 45 menit. Perlakuan pembelajaran yang diberikan kepada peserta didik dengan menggunakan media pembelajaran momentum, impuls dan tumbukan sebanyak 3 kali pertemuan.

TABEL 5. Rata-Rata Hasil Pre-Test dan Post-Test Pada Uji Coba Lapangan

\begin{tabular}{llll}
\hline Pre-Test & Post-Test & N-Gain & Kategori \\
\hline 20,47 & 71,88 & 0.65 & Sedang \\
\hline
\end{tabular}

TABEL 6. Rata-Rata Hasil Angket Respon Pesrta Didik

\begin{tabular}{lll}
\hline Aspek & Nilai Rata-Rata & Kategori \\
\hline Tampilan & 3.24 & Baik \\
\hline Materi & 3.17 & Baik \\
\hline Keterlaksanaan & 3.20 & Baik \\
\hline Rata-Rata & $\mathbf{3 . 2 0}$ & Baik \\
\hline
\end{tabular}

Dengan demikian, secara keseluruhan media pembelajaran yang dibuat peneliti berkategori baik berdasarkan penilaian peserta didik di kelas X-MIPA 1, X-MIPA 2 dan X-MIPA 3 SMA 17 Agustus 1945 Surabaya. 
Rata-rata nilai yang diperoleh pada pre-test adalah 20,47, sedangkan nilai rata-rata yang diperoleh pada saat post-test adalah 71,88. Dengan demikian terjadi peningkatan hasil belajar peserta didik dengan perolehan $\mathrm{N}$-Gain rata-rata 0,65 yang berkategori sedang. Peningkatan hasil belajar yang terjadi pada peserta didik ini membuktikan bahwa media pembelajaran berbasis papan permainan Jumanji Physics pada pokok bahasan momentum impuls di kelas X SMA 17 Agustus 1945 Surabaya dapat meningkatkan hasil belajar pada aspek pengetahuan.

\section{SIMPULAN}

Berdasarkan hasil pengembangan media pembelajaran berbasis papan permainan Jumanji Physics pada pokok bahasan Momentum Impuls untuk meningkatkan hasil belajar peserta didik kelas X SMA 17 Agustus 1945 Surabaya yang telah dilakukan oleh peneliti, dapat disimpulkan:

1. Kualitas media pembelajaran yang telah dikembangkan berdasarkan penilaian ahli, peer reviewer, dan angket respon peserta didik.

a. Berdasarkan hasil penilaian media oleh ahli, media yang dikembangkan dikategorikan sangat baik dengan nilai rata-rata sebesar 4,36.

b. Berdasarkan hasil penilaian media pembelajaran oleh peer reviewer, media yang telah dikembangkan dikategorikan sangat baik dengan nilai rata-rata sebesar 3,57.

c. Berdasarkan hasil angket respon peserta didik, media pembelajaran yang telah dikembangkan dikategorikan baik dengan nilai rata-rata sebesar 3,20.

2. Kevalidan perangkat perancanaan pembelajaran meliputi Rencana Pelaksanaan Pembelajaran (RPP) dan Rencana Evaluasi (RE).

a. Berdasarkan hasil validasi oleh ahli, Rencana Pelaksanaan Pembelajaran (RPP) yang telah dibuat dikategorikan valid dengan nilai rata-rata sebesar 3,08

b. Berdasarkan hasil validasi oleh ahli, Rencana Evaluasi (RE) yang telah dibuat dikategorikan sangat valid dengan nilai rata-rata sebesar 3,47.

3. Hasil uji coba lapangan pada peserta didik kelas X-MIPA 1, X-MIPA 2 dan X-MIPA 3 di SMA 17 Agustus 1945 Surabaya memberikan hasil sebagai berikut: Rata-rata Normalize Gain Score dari hasil pre-test dan post-test tersebut adalah sebesar 0,65 dan dikategorikan sedang.

4. Rata-rata keterlaksanaan RPP di kelas X-MIPA 1, X-MIPA 2 dan X-MIPA 3 untuk tiga pertemuan adalah sebesar 3,40 dan dikategorikan baik.

\section{REFERENSI}

[1] Arsyad, A,“Media Pembelajaran.” Jakarta: Raja Grafindo Persada, 2013

[2] Fandira, E., Wijaya, A., \& Noviani, E, P, F. "Heat And Monster Bingo" : An Instructional Board Game To Learn Temperature And Heat. Magister Scientiae Journal, 2016, Vol 2(44), 214-223

[3] Kuntjojo. "Metodologi Penelitian." Kediri: Universitas Nusantara PGRI Kediri, 2009

[4] Molenda, M. "In Search of the Elusive ADDIE Model." International Society for Performance Improvement Journal, 2003, Vol 42(5):34-36

[5] Pribadi, B. "Desain dan Pengembangan Program Pelatihan Berbasis Kompetensi: Implementasi Model ADDIE.” Jakarta: Prenada Media Group, 2016

[6] D. Djamas, R. Ramli, S. Y. Sari, and R. Anshari, "Analisis Kondisi Awal Pembelajaran Fisika SMAN Kota Padang (Dalam Rangka Pengembangan Bahan Ajar Fisika Multimedia Interaktif Berbantuan Game)", jpppf, vol. 2, no. 2, pp. 57 - 64, Dec. 2016.

[7] Karliana, N. F., Muliyati, D., \& Siahaan, B. Z. (2015). Pengembangan Naskah Drama Fisika sebagai Media Pembelajaran Fisika SMA berbasis Joyful Learning. Jurnal Penelitian \& Pengembangan Pendidikan Fisika, 1(2), 97-102. 
[8] I. A. Putri, S. Siswoyo, and W. Indrasari, "Pengembangan Media Pembelajaran Fisika Menggunakan Lectora Inspire pada Materi Usaha dan Energi SMA", jpppf, vol. 2, no. 2, pp. 71 - 78, Dec. 2016.

[9] S. Syahrowardi and A. H. Permana, "Desain Handout Multimedia Menggunakan 3D Pageflip Professional untuk Media Pembelajaran pada Sistem Android”, jpppf, vol. 2, no. 1, pp. 89 - 96, Jun. 2016.

[10] Sousa, M. J., \& Rocha, Á. (2019). Leadership styles and skills developed through game-based learning. Journal of Business Research, 94, 360-366. 